Reviews

community may offer better insights into the physical world we inhabit.

Part Four of Fluid Arguments presents a reevaluation of the role of damming projects in the history of water development. Donald Jackson indicates that the private sector played a crucial role in the creation of these publicworks projects, while Mark Harvey explores the massive dams constructed pursuant to the New Deal. As noted by Char Miller, "The stunning complex of dams along the Colorado, Platte, Snake, Columbia and Missouri Rivers degraded riparian ecosystems, inundated natural landmarks, uprooted communities, and turned fast-flowing watercourses into placid reservoirs. They also produced considerable work in a region of high unemployment, generated cheap hydroelectricity to power new industries on the West Coast, and sparked the emergence of a potent political coalition that channeled federal spending into these ambitious projects." As for the aftermath, legal scholar Raul Sanchez surveys the high price paid by individuals and the environment for these initiatives.

Finally, Fluid Arguments turns to the challenges for the future. University of Nevada History Professor Hal Rothman argues that reallocation may present the wave to come. "When Nevadans look to the fact that more than 80 percent of their water produces only $\$ 1$ billion in revenue and realize that 18 percent accounts for more than three hundred times that amount in gross revenue, they cast their eyes on the rural parts of the state with wonder."

Rothman suggests that the urban economy will eventually demand a greater share of water resources, and will "create considerably more opportunity for more people throughout the state" than water-intensive agricultural operations in an arid setting.

Given the prominence of water in the development of communities in the West, perhaps it is time to revisit allocation rules and come up with a reasoned approach to water usage. "First in time, First in right" provides predictability as a rule, but does not necessarily ensure a wise use of this limited resource. The Kiowa story of Saynday acknowledges that water brings us home; it is the guide for our communities and the center of our existence in the arid American West. In addition, water can bring diverse peoples to the table to discuss common interests and create common goals. Fluid Arguments provides a solid foundation for this discussion to proceed. As John Muir once observed, "Nature is always lovely, invincible, glad, whatever is done and suffered by her creatures. All scars she heals, whether in rocks or water or sky or hearts."

\title{
Marketing Democracy: Power and Social Movements in Post-Dictatorship Chile, by Julia Paley. Berkeley and Los Angeles: University of California Press, (2001), xviii, 255, pp.
}

\section{Reviewed by Edward Murphy, Department of Anthropology and History, University of Michigan.}

In Marketing Democracy: Power and Social Movements in Post-Dictatorship Chile (Berkeley and Los Angeles: University of California Press, 2001), Julia Paley provides a challenging and thoughtful critique of contemporary Chilean democracy. Countering the dominant interpretation of Chile as an economic and political model for "developing" countries, Paley's perspective as an activist anthropologist allows her to probe the multifaceted inequities of neo-liberalism. Anchoring her writing to the experiences of neighborhood leaders in La Bandera, one of Santiago's impoverished poblaciones [1], Paley demonstrates how Chileans have struggled to mobilize and criticize the democracy that has evolved in the wake of Augusto Pinochet's military dictatorship (1973-1990). Writing in descriptive and accessible prose, Paley raises a series of critical questions about the nature of governance in a country and era ostensibly committed to "democracy," "participation," and "growth with equity."

Acutely aware that knowledge production can contribute to unequal relationships of power, Paley attempts to transcend her position as a privileged foreign researcher by treating her local informants as "intellectual colleagues" (14). In fact, many of the theoretical perspectives in the book build on positions put forward by pobladores, especially the work of activists in the health group Llareta. Attempting to understand the social causes of poor health in La Bandera, Llareta members seek to combat illness among poblador residents by both administering medical assistance and educating and mobilizing residents to improve conditions. Through her intellectual exchange with these activists, Paley hopes to provide a practical critique of the larger processes that pobladores endure, resist, and partially help to create.

Paley's focus on one población and her own activism in it has two important advantages. First, she is able to understand how social movements operate in practice, as she became a participant in the processes that she 
Reviews

describes. By organizing activities in La Bandera and presenting her own work to the pobladores, Paley received first hand experience in holding popular education seminars and the obstacles faced by community leaders in confronting state officials. Second, she is able to provide telling glimpses of the inequalities and degradation that many Chileans continue to suffer during the Chilean economic "miracle." This includes descriptions of flooding in the poblaciones, lack of adequate housing and nutrition, the second hand clothes from the United States that pobladores often buy, and the ill effects of garbage accumulation in public spaces. Through oral testimony and firsthand observation, she also relates how poblador community leaders were often dismissed in public forums because they lacked academic degrees and prestigious positions.

In attempting to understand the forces that have shaped these conditions, however, Paley appropriately moves far beyond the specifics of La Bandera. In writing an "ethnography of democracy," Paley examines the political elites who forged Chile's democratic transition, situating them within international discourses of development and neo-liberalism (111-113). In developing the central argument of her book, Paley explores how these policy-makers have linked democracy to free market economic policies. For Paley, a "marketed democracy" has emerged in Chile, one which sells neo-liberalism and an electoral political system as steps towards national reconciliation and development. But this particular project of democracy, as the case of La Bandera well illustrates, continues to leave victims in its wake.

Paley claims that the roots of this constricted democracy lie in the Pinochet dictatorship. While elite politicians in the ruling center-left Concertación have sought to draw a clear distinction between the dictatorship and democracy, Paley points out that there have been a number of continuities between the two eras. Most importantly, the Concertación has remained faithful to the neo-liberal economic model that demands fiscal austerity from the state. Consequently, state spending in social services has not significantly increased since the advent of democracy. Moreover, economic and social policies have continued to be determined by a small group of highly educated technocrats. Although the Concertación's experts are less orthodox in their economic policies, they nonetheless deploy the same kind of professional knowledge that came to be revered during the dictatorship. Moreover, they also reject mobilizing popular sectors, relying instead on finding technical answers to poverty. Such a valorization of professional knowledge underscores a lack of respect for the poor that constructs them "as objects of knowledge and policy rather than as knowing subjects with rights" (195).

By examining how such knowledge operates in the post-dictatatorship, Paley questions conventional interpretations of "democracy" and "participation." Focusing on social movements in recent Chilean history, Paley explores how pobladores had been mobilized during the pre-dictatorship years and during the national protests against the Pinochet regime (1983-1986). Few popular organizations, however, continued to exist in the first years of democracy. For those organizations that did remain, such as the health group Llareta, critiques of government policies had to be couched in the same forms of professional knowledge in use by government officials, such as surveys and statistics (192-195). While Paley argues that such forms of knowledge can be helpful in contradicting erroneous, dominant perspectives, Paley also laments that they have been used to forge a fractured national project of "democracy." For example, Paley examines how the Concertación has used opinion surveys in order to understand the aspirations of citizens (131-139). Paley is able to demonstrate, however, that these polls constrict public debate by asking pre-conceived questions that have limited responses. Far from eliciting a forum for public debate, such polls legitimize frameworks established by elites. Underscoring the social links between politics and economics, Paley points out that these types of surveys are used by government officials, social science researchers, and private companies.

While opinion polls grant a false sense of political voice to citizens, Paley also argues that the Concertación has constricted the participation of community activists. In the Concertación's attempts to forge national reconciliation and consensus, community groups are expected to support the national government as it builds and "consolidates" democracy. Groups of "civil society" are thus expected to "participate" in this project of nation building. As both Paley and members of the health group Llareta argue, however, this has often meant that activists have been forced into providing community services. Government officials thus abdicate responsibility for community development, claiming that it is the democratic responsibility of the people to identify and solve local problems. In practice, this often means that impoverished pobladores have to implement projects for free. Moreover, this conception of participation curtails protest against the government by both investing local actors in the system and demanding their support for democracy. Paley thus demonstrates that "participation" has reinforced the particular governing project of the Concertación rather than creating an effective space for citizens to participate in building their own society.

While Paley provides a thorough analysis of the democratic transition, her micro-historical examination of La Bandera lacks the depth of her ethnographic work. In the first chapter, Paley relates how the community was founded during the final years of Eduardo Frei Montalva's Christian Democratic regime (1964-1970) and Salvador 
Reviews

Allende's socialist experiment (1970-1973). Since Paley is explicitly in solidarity with the people of La Bandera, she constructs a particular narrative of the población, one which privileges a history of collective action and the common historical experiences of the impoverished classes. For Paley, the history of La Bandera demonstrates how popular practices that became common before the coup, such as organized land takings, permitted pobladores to build their own communities and assume a shared identity in struggle. As Paley argues, such a perspective counters the historical narrative of many officials from the dictatorship and the Concertación, who have often cast the popular protagonism of the late 1960s and early 1970s as fomenting conflict and disorder (36). Paley's historical analysis thus serves a very important political end.

Nevertheless, Paley's treatment largely relegates the problem of knowledge and power to the specific time and place of the democratic transition, failing to engage with the historical persistence of this issue. Paley is aware that professional knowledge was also important before the coup, but makes a clear distinction to the situation in the post-dictatorship. Paley argues that a "different cultural premise framed the actions of Chilean politicians" in the late 1960s and early 1970s (198), one which privileged their commitment to the class struggle. Beyond homogenizing a diverse spectrum of politicians-- many of whom were more than satisfied in trusting professional knowledge-- Paley fails to recognize sufficiently how certain politicians of the left also resisted "popular power." As Peter Winn (1986) has demonstrated, there was a constant tension between how far government elites would permit "popular power" to go during the Popular Unity years and how officials in the government sought to control the course of the revolution. Government planners often felt that popular actions upset the "rational" and "orderly" development of the city (MINVU 1969: 529-555; see also Salvador Allende's comments in R. Debray 1971: 88).

Despite this problem in her historical presentation, Marketing Democracy is an excellent book that deserves a wide audience. Her ability to bring anthropological insights to bear on the nature of democratic governance and social movements in the neo-liberal era adds an important perspective to a literature largely dominated by political science and sociology. Moreover, Paley's position as an activist should be of interest to non-academics involved in local activism, particularly those who seek to understand how more general, global forces impact social movement organizing.

[1] Paley wisely uses the term población in her book, and refers to La Bandera's residents as pobladores. Many authors writing in English have loosely and inappropriately referred to the poblaciones as shantytowns. But the word shantytown hardly does justice to the possible connotations of the Chilean signifier población. One of Chilean society's most prominent markers of socioeconomic distinction, English expressions such as "ghetto," "slum," and "working class neighborhood" come closer to expressing some of the multivalent meanings of población. However, at least in the American context, they tend not to express the pride, solidarity, and nationalism that the word has often conveyed in Chile. Because the term has multiple and specific meanings, Paley sticks to using the term itself in her book, demonstrating through context the social importance that the term conveys. Similarly, in referring to a resident of a población, Paley also uses the Chilean expression, pobladora or poblador.

\section{References Cited:}

Debray, Regis.

1971. Conversations with Allende: Socialism in Chile (London: NLB).

MINVU (Ministerio de Vivienda y Urbanismo). 1969. Mensaje Presidencial: Informe del Ministerio de Vivienda y Urbanismo. (Santiago: MINVU)

Winn, Peter.

1986. Weavers of Revolution. (New York and Oxford: Oxford University Press). 